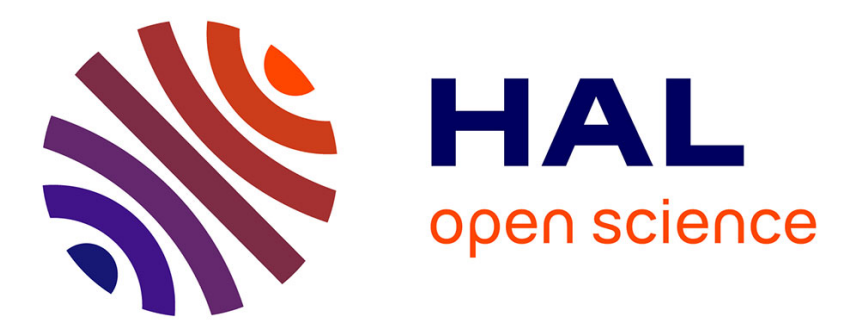

\title{
Suitability of pollen as an alternative food source for different developmental stages of Amblyseius herbicolus (Chant) (Acari: Phytoseiidae) to facilitate predation on whitefly eggs
}

Tian-Rong Xin, Zhi-Qiang Zhang

\section{To cite this version:}

Tian-Rong Xin, Zhi-Qiang Zhang. Suitability of pollen as an alternative food source for different developmental stages of Amblyseius herbicolus (Chant) (Acari: Phytoseiidae) to facilitate predation on whitefly eggs. Acarologia, 2021, 61 (4), pp.790-801. 10.24349/bIV1-2heN . hal-03361028

\author{
HAL Id: hal-03361028 \\ https://hal.science/hal-03361028
}

Submitted on 1 Oct 2021

HAL is a multi-disciplinary open access archive for the deposit and dissemination of scientific research documents, whether they are published or not. The documents may come from teaching and research institutions in France or abroad, or from public or private research centers.
L'archive ouverte pluridisciplinaire HAL, est destinée au dépôt et à la diffusion de documents scientifiques de niveau recherche, publiés ou non, émanant des établissements d'enseignement et de recherche français ou étrangers, des laboratoires publics ou privés. 


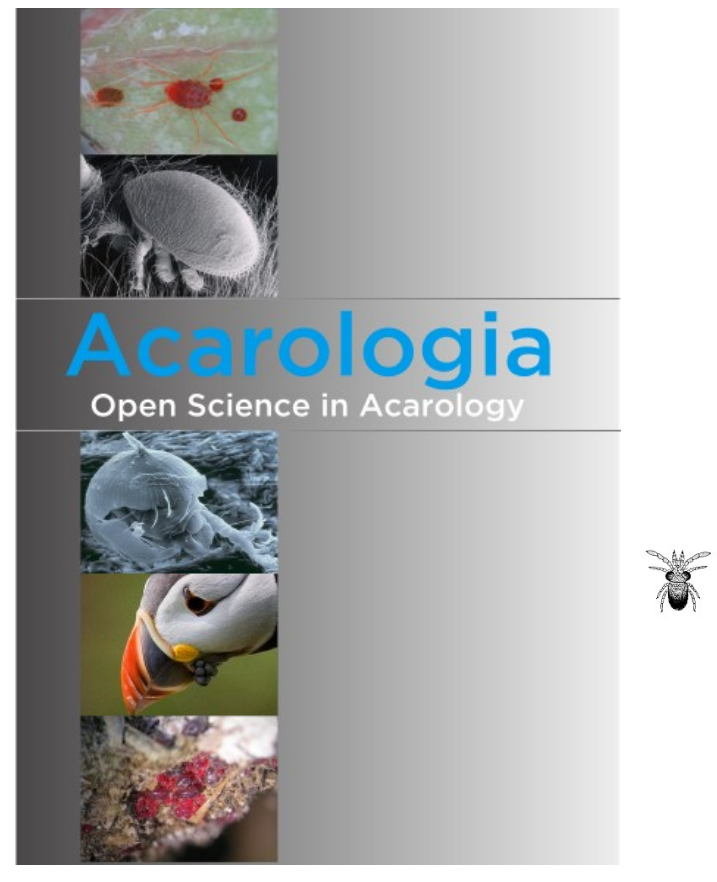

\section{Acarologia}

A quarterly journal of acarology, since 1959

Publishing on all aspects of the Acari

All information:

http://www1.montpellier.inra.fr/CBGP/acarologia/

acarologia-contact@supagro.fr

\section{OPEN ACCESS}

\section{Acarologia is proudly non-profit, with no page charges and free open access}

Please help us maintain this system by encouraging your institutes to subscribe to the print version of the journal and by sending us your high quality research on the Acari.

Subscriptions: Year 2021 (Volume 61): $450 €$ http://www1.montpellier.inra.fr/CBGP/acarologia/subscribe.php

Previous volumes (2010-2020): $250 €$ / year (4 issues)

Acarologia, CBGP, CS 30016, 34988 MONTFERRIER-sur-LEZ Cedex, France

ISSN 0044-586X (print), ISSN 2107-7207 (electronic)

The digitalization of Acarologia papers prior to 2000 was supported by Agropolis Fondation under the reference ID 1500-024 through the «Investissements d'avenir » programme

(Labex Agro: ANR-10-LABX-0001-01)
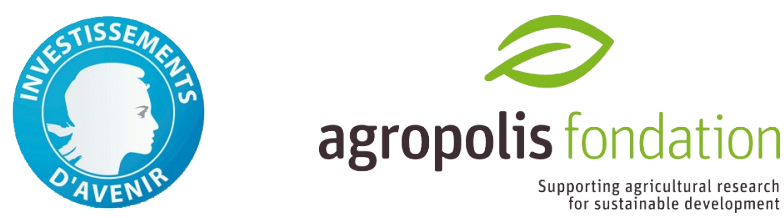

Acarologia is under free license and distributed under the terms of the Creative Commons-BY. 


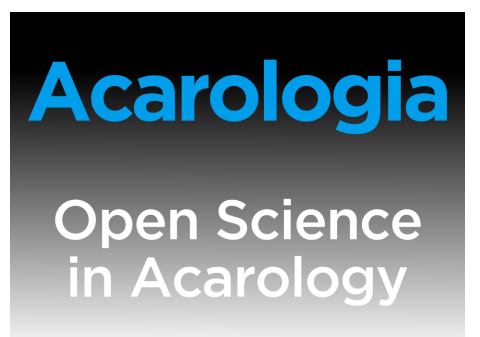

Received 08 May 2021

Accepted 24 September 2021

Published 01 October 2021

Corresponding author

Zhi-Qiang Zhang (D):

ZhangZ@landcareresearch.co.nz

Academic editor

Palevsky, Eric

\section{https://doi.org/}

10.24349/bIV1-2heN

ISSN 0044-586X (print)

ISSN 2107-7207 (electronic)

Copyright

Xin T. and Zhang Z.

Distributed under

Creative Commons CC-BY 4.0

\section{Suitability of pollen as an alternative food source for different developmental stages of Amblyseius herbicolus (Chant) (Acari: Phytoseiidae) to facilitate predation on whitefly eggs}

\author{
Tian-Rong Xin ${ }^{a}$, Zhi-Qiang Zhang (iD ${ }^{b}$ \\ ${ }^{a}$ School of Life Sciences, Nanchang University, Nanchang, China. \\ ${ }^{b}$ Manaaki Whenua - Landcare Research, Auckland and School of Biological Sciences, The University of \\ Auckland, Auckland, New Zealand.
}

\section{Original research}

\section{ABSTRACT}

Alternative food sources could sustain predator populations by influencing their performances including predation, development, and reproduction in periods of shortage or scarcity of prey under laboratory or fields conditions. The aim of this study was to explore suitability of cattail pollen (Typha orientalis) as an alternative food source for different stages of Amblyseius herbicolus (Chant) (Acari: Phytoseiidae) on their predation capacity against the eggs of whitefly Trialeurodes vaporariorum (Westwood) (Hemiptera: Aleyrodidae), and the developmental and reproductive responses of the predators to different diet switching regimes under laboratory conditions (T1: nymphs and early adults fed pollen; T2: nymphs fed pollen but early adults fed whitefly eggs; T3: nymphs fed whitefly eggs but early adults fed pollen; T4: nymphs and early adults fed whitefly eggs). Results in the diet switching experiment revealed that although $A$. herbicolus could prey on whitefly eggs in all the treatment groups, the predatory mites obviously differed in their capacity to prey on the target pest whitefly eggs when fed on cattail pollen and whitefly eggs during different developmental stages. A. herbicolus in group T2 revealed the highest average predation rate, being $1.31,1.17$, and 1.49 times those in groups $\mathrm{T} 1, \mathrm{~T} 3$, and $\mathrm{T} 4$, respectively. Our results indicated that food sources including cattail pollen and whitefly eggs were suitable for $A$. herbicolus, because it was able to develop from egg to adult females in all the treatment groups. The mixed diets (T2 and T3 groups) revealed positive effects on the developmental and reproductive parameters of $A$. herbicolus females, leading to higher oviposition rates and shorter developmental durations when compared with those of groups T1 and T4. A. herbicolus in group T2 revealed the highest average oviposition rates (1.32, 1.26, and 1.81 times those in groups $\mathrm{T} 1, \mathrm{~T} 3$ and $\mathrm{T} 4$, respectively); however, no significant differences were observed between the T1 and T3 groups. All the eggs of $A$. herbicolus succeeded in reaching adulthood, but the duration of egg to adult developmental time of A. herbicolus was different among the four treatment groups. The longest and shortest developmental times were obtained in groups T4 and T3, respectively. All the results in the present study demonstrated that $A$. herbicolus adult females can prey on $T$. vaporariorum eggs, and cattail pollen was suitable as an alternative or additional food source with high nutritional value for this predatory mite to enhance the predation capacity towards whitefly eggs because $A$. herbicolus can successfully complete its immature development as well as reproduction.

Keywords Amblyseius herbicolus ; whitefly ; alternative food ; suitability ; predation ; biological control 


\section{Introduction}

Whiteflies, thrips, aphids, spider mites, and leafminers include some of the most important pests in solanaceous greenhouse crops and can lead to serious yield losses on a global scale (Perdikis et al., 2008). Among 1556 species of whiteflies in the world (Martin and Mound, 2007), the greenhouse whitefly, Trialeurodes vaporariorum (Westwood) and the tobacco whitefly, Bemisia tabaci (Gennadius) (Hemiptera: Aleyrodidae) are the most important and destructive species in open field and greenhouse crops worldwide. Whiteflies suck and remove plant sap using mouthparts to reduce yield and weaken plant photosynthesis. Whitefly adults and nymphs feed on plant phloem and excrete a large amount of honeydew, which is a sugary substance for the development of saprophytic fungal mould, leading to lower fruit quality due to leaf/fruit blackening and reduced photosynthesis on covered leaves and fruits. In addition, whiteflies transmit numerous plant viruses (Perdikis et al., 2008; Lee and Zhang, 2018; Spence et al., 2020). Trialeurodes vaporariorum has a wide host range, attacking 859 species of plants from 469 genera and 121 families (CABI 2017). Additionally, Burnett (1949) reported the fecundity and longevity of females at temperatures ranging from $9{ }^{\circ} \mathrm{C}$ to $33^{\circ} \mathrm{C}$, and maximum longevity at $15{ }^{\circ} \mathrm{C}$, with very short survival at $9{ }^{\circ} \mathrm{C}$ and temperatures over $27{ }^{\circ} \mathrm{C}$ and many generations every year. Moreover, $T$. vaporariorum was known to have high reproductive rates, reaching an average of 320 eggs per female throughout the life cycle (Burnett, 1949). Furthermore, whiteflies have rapidly developed resistance to many chemical pesticides because of the frequent application of synthetic insecticides to suppress whitefly populations (Spence et al., 2020). All the biology and life history parameters of T. vaporariorum indicate that the effective management of this most economically important species has become a major challenge.

Biological control is the most prominent and sustainable method worldwide in integrated pest management (IPM) in agriculture, especially in greenhouse crops. It is necessary because crops are harvested frequently over short intervals, and thus the intensive use of chemicals becomes questioned due to the possible contamination of products with chemical residues (Perdikis et al., 2008). Biological control against insect and mite pests has taken environmentally friendly advantages over the conventional chemical control, including neither resistance development, nor risk in subsequent pesticide residues in food and environment. Numerous studies revealed that biological control of whitefly populations based on using a wide variety of parasitoids and predators has proved very successful on several crops (Perdikis et al., 2008; Lee and Zhang, 2018; Medd and GreatRex, 2014). The data indicated that 24 predator and 21 parasitoid species were reported to control T. vaporariorum, and 48 predators and 33 parasitoids were known for controlling B. tabaci (CABI, 2017). Ladybird beetles are prominent natural enemies of whiteflies and known to prey successfully on B. tabaci and T. vaporariorum. The results of prey consumption preferences demonstrated that larvae and adults of Serangium parcesetosum Sicard (Coleoptera: Coccinellidae) could prey on all whitefly immature stages, and all $S$. parcesetosum stages could also effectively prey on $B$. tabaci and $T$. vaporariorum at both low and high temperatures $\left(18^{\circ} \mathrm{C}\right.$ and $\left.30^{\circ} \mathrm{C}\right)$ (Al-Zyoud and Sengonca, 2004). Greenberg et al. (2002) reported that two parasitoid species, Eretmocerus eremicus Rose \& Zolnerowich and Eretmocerus mundus Mercet (Hymenoptera: Aphelinidae), could efficiently attack both whitefly species, Bemisia argentifolii Bellows \& Perring and T. vaporariorum (Westwood) on tomato. Apart from these insect predators, recent studies have revealed that predatory mites of the Phytoseiidae family were widely used to control infestations of whiteflies. Among them, Amblyseius swirskii Athias-Henriot has been reported as an effective natural enemy for suppressing whitefly populations due to its high intrinsic rate of increase and its ability to utilize alternative food sources such as pollen and prey-produced honeydew (Nomikou et al., 2003). Provision of pollen as supplementary food could enhance population build up and predation efficiency over either a suitable or a marginal suitable prey species (Pappas et al., 2013; Samaras et al., 2019, 2021). Amblydromalus limonicus has been reported as a crucial biological control agent against $T$. vaporariorum in the greenhouse environment (Knapp et al., 2013; Lee and 
Zhang, 2018). Amblyseius swirskii is also an important predator of the whitefly, Aleuroclava jasmini (Takahashi) on paper mulberry in Iran (Shahbaz et al., 2019). Three predatory mite species - A. swirskii, Typhlodromips montdorensis (Schicha), and Amblydromalus limonicuscould suppress greenhouse whitefly (T. vaporariorum) populations (Medd and GreatRex, 2014). Amblyseius tsugawai Ehara, and Amblyseius orientalis (Ehara) could also prey on whitefly eggs (Yang et al., 2019; Zhang et al., 2015). Recently, the predatory mite Neoseiulus bicaudus (Wainstein) was shown to be a promising biocontrol agent of the whitefly B. tabaci (Han et al. 2020).

Numerous recent studies, focusing on evaluating diet suitability of alternative/supplementary food sources for predatory mites in biological control of pest species may become the emerging novel topics in nutritional ecology. These non-prey food sources not only allowed the predators to sustain the population in the event of prey scarcity, but also were valuable for rearing predators in laboratories or mass rearing for biological control (Khanamani et al., 2017). A previous study indicated that different types of alternative food sources, including pollens (cattail, maize, and apple) and eggs of the Mediterranean flour moth Ephestia kuehniella, were all suitable for Amblyseius swirskii and Neoseiulus cucumeris, and both predatory species were able to develop and reproduce when fed with these pollens as well as moth eggs (Delisle et al., 2015). Bouvet et al. (2019) evaluated the suitability of the two most abundant aphid species in citrus agroecosystems, Aphid gossypii and A. spiraecola, for their principal natural enemies, the coccinellid predators Scymnus subvillosus and S. interruptus. Results indicated that the fitness of both predators when offered a mixed diet of both aphids was higher than that fed only a single aphid species. A previous study suggested that non-prey food sources such as cattail pollen and whitefly-produced honeydew were suitable for the survival, development, and reproduction of two phytoseiid species, Euseius scutalis (Athias-Henriot) and Typhlodromips swirskii (Athias-Henriot) (Nomikou et al., 2003). The laboratory trials performed by Pirayeshfar et al. (2020) revealed that immature stages (mixed living, frozen eggs or frozen larvae) of astigmatid mites (Tyrophagous putrescentiae) as a supplementary food source strongly affected the diet suitability for $A$. swirskii by influencing the predatory mite's developmental times and oviposition rates. Interestingly, the result of Soltaniyan et al. (2018) revealed that pistachio pollen (Pistacia vera) could be a more suitable alternative food source for the development and reproduction of Neoseiulus californicus than its natural prey T. urticae because of shorter previposition periods and higher fecundity.

The predatory mite, Amblyseius herbicolus Chant (Acari: Phytoseiidae) is widely established throughout New Zealand (Ma et al., 2019) as well as being commonly found in many countries (Argov et al., 2002; Cavalcante et al., 2015; Döker et al., 2014; Hajizadeh and Nazari, 2012). According to the classification of lifestyles of phytoseiid mites, it is considered a generalist facultative predator (type III) that can feed on many species of prey (mites and small insects) as well as a variety of plant-derived foods (McMurtry et al., 2013). It is an important predator of multiple pest mite species such as the broad mite Polyphagotaronemus latus (Banks) (Duarte et al., 2015; Rodríguez-Cruz et al., 2013), false spider mite Brevipalpus phoenicis (Geijskes) (Reis et al., 2007), citrus rust mite Phyllocotruta oleivora (Ashmead) (Argov et al., 2002), and spider mites Tetranychus urticae Koch (Moghadam et al., 2010). It has been reported to attack small insects such as thrips (Pseudodendrothrips mori (Niwa) and Sericothrips staphylinus Haliday) (Lam et al., 2019) and whitefly B. tabaci (Gennadius) (Cavalcante et al., 2015). It can also feed on many non-prey food sources, including honeydew, nectar, and pollen grains from different plant species (Hoogerbrugge et al., 2011; Marcossi et al. 2020; Moghadam et al., 2010). The wide distribution and range of suitable food sources for this species suggest it could well adapt to extensive natural environments, including greenhouses and fields. Accordingly, the aim of the present study was to explore the suitability of cattail pollen (Typha orientalis) as an alternative food source for different stages of $A$. herbicolus in their predation capacity against whitefly eggs $T$. vaporariorum and the developmental and reproductive responses of the predators to different diet-switching regimes under laboratory conditions. 


\section{Materials and methods}

\section{Plants}

The seedlings of Solanum mauritianum and Solanum nigrum were respectively grown from seeds in small plastic pots $(30 \mathrm{~cm}$ height, $20 \mathrm{~cm}$ diameter) filled with potting soil. These plants were placed inside a mesh cage $(52 \times 52 \times 72 \mathrm{~cm})$, watered twice per week, and kept at approximately $25^{\circ} \mathrm{C}, 60 \pm 10 \%$ relative humidity and a natural photoperiod in the greenhouse at Landcare Research, Auckland, New Zealand. None of the plants were ever exposed to any pesticides.

\section{Stock colonies of whitefly and predatory mite}

Trialeurodes vaporariorum colony was reared on the seedlings of $S$. mauritianum in a greenhouse at Landcare Research. These whitefly-infested solanaceous plants were enclosed inside mesh cages. The whitefly rearing was continuous and required a fresh batch of whiteflyinfested $S$. mauritianum plants once every two weeks.

The predatory mite, Amblyseius herbicolus (about 60 adult females) was initially collected from Pittosporum crassifolium (Karo) leaves on the campus of Landcare Research in St John, Auckland. The stock population was maintained in a climate controlled cabinet at approximately $25 \pm 1{ }^{\circ} \mathrm{C}, 70 \pm 5 \% \mathrm{RH}$ and 16:8 h photoperiod (Light: Dark) at Landcare Research, Auckland. The population was supplied with $T$. orientalis pollen as the food source. Part of their progeny was used for morphological species identification (Ma et al., 2019) and the reminder of the progeny was maintained to establish the laboratory colony for use in the present study. Briefly, the phytoseiid stock culture of $A$. herbicolus was reared on a black PVC sheet (approximately $15 \mathrm{~cm} \mathrm{x} 10 \mathrm{~cm}$, with 12 holes of $0.5-\mathrm{mm}$ diameter) placed on black tissue-papers wrapped over the edge of the water-saturated sponge in a plastic tray filled with water according to the protocols described by Patel \& Zhang (2017). A few cotton threads were added underneath a white plastic sheet (about $1-2 \mathrm{~cm}^{2}$ ), functioning as shelter and substrate for oviposition for the predatory mites. T. orientalis pollen was dusted on these sheets with a brush twice every week.

\section{Preparation of developmentally synchronized $T$. vaporariorum eggs}

The experiments were conducted on detached S. nigrum leaves cut from the first leaves of 2week-old plants. Before the experiment, leaves were checked for the presence of any arthropods under a stereomicroscope and only the leaves without arthropods were used in the following experiment. The cohorts of whitefly eggs were used in the laboratory experiments. In order to prepare whitefly eggs in synchronized development, many experimental arenas were created, according to Li \& Zhang (2016): each experimental arena contained two plexiglass slides clipped together at the sides: the top slide was $38 \mathrm{~mm}$ wide, $38 \mathrm{~mm}$ long and $3 \mathrm{~mm}$ thick, with a 16-mm-diameter hole in the middle, and the bottom slide was covered with a piece of freshly detached $S$. nigrum leaf that was placed upside-down on the black water-soaked tissue-paper. Approximately 20 adult whiteflies were collected with a fine hairbrush from $S$. mauritianum leaves in the greenhouse, subsequently transferred into each experimental arena, covered with a coverslip, and then incubated at $25 \square$ and 16:8 LD for $24 \mathrm{~h}$. During that time, the adult female whiteflies laid eggs on the $S$. nigrum leaf discs. After one day, the adult females were removed from the leaf disc with a brush without damaging the eggs left on the leaf disc. The eggs laid by $T$. vaporariorum adults were used as a food source for nymphs or adult mites of $A$. herbicolus in the different experimental treatments. The number of the whitefly eggs was adjusted to twenty per leaf disc with a thin entomological needle and each leaf disc was used as an experimental arena. Our preliminary predation tests suggested that the amounts of whitefly eggs were sufficient and could meet the maximum prey consumption of the predators. 


\section{Preparation of the predatory mites synchronized in development}

Amblyseius herbicolus displays thelytokous parthenogenesis in its reproduction (De Moraes \& Mesa, 1988), so adult female mites were used in this laboratory experiment. To produce the large cohorts of newly molted adult female mites that were synchronized in their development, 40 adult female mites were transferred from the stock rearing colony to the new plastic arenas (approximately $15 \mathrm{~cm}$ x $10 \mathrm{~cm}$ ) placed on black tissue-papers and sponges in a plastic tray containing water, and the adult females were allowed to lay eggs at $25{ }^{\circ} \mathrm{C}$ for $24 \mathrm{~h}$ before removal. These developmentally synchronized eggs of $A$. herbicolus were maintained with $T$. orientalis pollen until they reached protonymphs, which were used in the following experimental treatments.

\section{Experimental design}

To evaluate the effects of pollen and T. vaporariorum eggs on the performance of $A$. herbicolus, the following treatments were conducted:

- T1: Pollen (protonymph and deutonymph) + pollen (adult female).

- T2: Pollen (protonymph and deutonymph) + whitefly egg (adult female).

- T3: Whitefly egg (protonymph and deutonymph) + pollen (adult female).

- T4: Whitefly egg (protonymph and deutonymph) + whitefly egg (adult female).

Developmentally synchronized eggs of $A$. herbicolus prepared in the last section were used in the experiments and were transferred individually to each rearing arena of each treatment. A total of 24 eggs of $A$. herbicolus were used per treatment. In two treatments (T1 and T4), either pollen or whitefly eggs alone were given to them as a food source during immature stages and adults throughout the experiments. In T3 and T4 treatments, there was diet switching: when the eggs of predatory mites developed to protonymphs and deutonymphs, whitefly eggs (T3) or pollen (T2) were given to them as a food source; but when the deutonymphs molted and developed to adult mites, their food was switched to pollen or whitefly eggs, respectively. In the present study, the whitefly eggs were renewed daily to keep them fresh and at a density of 20 eggs per leaf disc during the experiment.

\section{Predation, survival, and reproduction of the predatory mite $\boldsymbol{A}$. herbicolus}

All the developmentally synchronized adult female mites that were treated according to above experimental treatments (T1, T2, T3 and T4) were individually starved for 24 hours before being used in this experiment. Each $A$. herbicolus adult female was transferred to an experimental arena containing twenty whitefly eggs, and the top slide of each experimental arena was then covered with a piece of transparent cling film punctured with an insect pin to allow ventilation and the maintenance of humidity. All the experiments were conducted in a room at $25 \pm 1{ }^{\circ} \mathrm{C}$, $60 \pm 10 \% \mathrm{RH}$ and 12:12 h (L:D) photoperiod. After 24 hours, twenty whitefly eggs of each experimental arena in every treatment were renewed to ensure sufficiently fresh prey supply. The number of whitefly eggs consumed and the number of eggs laid by each predatory mite within 24 and 48 hours were recorded, respectively. All the predatory mites were removed with the brush. Each egg laid by each female mite was then individually transferred to a new separate rearing arena and supplied with $T$. orientalis pollen as a food source every other day until the mites reached adulthood. The survival and the developmental stages of the offsprings' generation of experimental females were checked under the stereoscopic microscope and recorded daily. 


\section{Statistical analysis}

The predation rates, oviposition rates, and developmental durations of immature stages of $A$. herbicolus were analyzed using one-way analysis of variance (ANOVA); all mean comparisons with Duncan's test at $P<0.05$ were considered to have statistically significant differences. The statistical analyses were conducted using the package software SPSS v.20.0 (Chicago, IL, USA).

\section{Results}

\section{Predation rates of $\boldsymbol{A}$. herbicolus adult females on $\boldsymbol{T}$. vaporariorum eggs}

The predation rates of $A$. herbicolus adult females on $T$. vaporariorum eggs were statistically different among the four groups $(P<0.05$; Table 1). The highest and lowest predation rates of A. herbicolus were exhibited in groups T2 (young adults exposed to whitefly eggs) and T4 (both immature and adults exposed to whitefly eggs), respectively. A. herbicolus in group T2 at day 1 consumed 1.31, 1.16, and 1.50 times those in groups T1, T3 and T4, respectively. In addition, at day 2 , the highest and lowest predation rates of $A$. herbicolus were exhibited in groups T2 and T4, respectively. However, no significant differences in predation rates of $A$. herbicolus were found between groups $\mathrm{T} 1$ and T3. A. herbicolus in the experimental group T2 at day 2 had the highest predation rate, which was 1.31, 1.21, and 1.60 times that in groups T1, T3, and T4, respectively. As for the average predation rate of $A$. herbicolus adult female on $T$. vaporariorum egg within two days, predation rates among the four groups revealed statistically different significances $(P<0.05)$ : the highest and lowest predation rates of $A$. herbicolus were recorded in groups T2 and T4, respectively. A. herbicolus in experimental group T2 revealed the highest average predation rate: $1.31,1.17$, and 1.49 times that in groups T1, T3 and T4, respectively.

\section{Development and reproduction of $A$. herbicolus fed on Typha orientalis pollen or $T$. vaporariorum egg}

Although there were no statistically significant differences in the developmental durations of egg and larvae of $A$. herbicolus within the four groups $(P>0.05)$, the developmental times of the protonymph and deutonymph stages of $A$. herbicolus revealed obvious differences (Table 2 ). The longest developmental durations for $A$. herbicolus protonymphs and deutonymphs were observed in groups T2 and T4, respectively. The developmental time of $A$. herbicolus protonymphs in group T2 was 1.15, 1.11, and 1.03 times those in groups T1, T3 and T4, respectively. Similarly, the developmental time of $A$. herbicolus deutonymphs in group T4 was $1.09,1.18$, and 1.20 times those in groups T1, T2, and T3, respectively. Taken together, all the eggs succeeded in reaching adulthood, but the duration of egg to adult developmental time of $A$. herbicolus was obviously different among the four treatment groups. The longest and shortest

Table 1 Predation rates by adult female of Amblyseius herbicolus on Trialeurodes vaporariorum egg and cattail pollen (Typha orientalis) after 24 and $48 \mathrm{~h}\left(25 \pm 1{ }^{\circ} \mathrm{C}, 60 \pm 10 \% \mathrm{RH}\right.$ and 12:12 $\mathrm{h}$ (L:D) photoperiod).

\begin{tabular}{cccc}
\hline Treatment & Day 1 & Day 2 & Total \\
\hline T1 & $11.08 \pm 0.11 \mathrm{c}$ & $2.54 \pm 0.15 \mathrm{bc}$ & $13.63 \pm 0.07 \mathrm{c}$ \\
$\mathrm{T} 2$ & $14.54 \pm 0.11 \mathrm{a}$ & $3.33 \pm 0.15 \mathrm{a}$ & $17.79 \pm 0.25 \mathrm{a}$ \\
$\mathrm{T} 3$ & $12.50 \pm 0.19 \mathrm{~b}$ & $2.75 \pm 0.22 \mathrm{~b}$ & $15.25 \pm 0.31 \mathrm{~b}$ \\
$\mathrm{~T} 4$ & $9.67 \pm 0.11 \mathrm{~d}$ & $2.08 \pm 0.11 \mathrm{c}$ & $11.92 \pm 0.11 \mathrm{~d}$ \\
\hline
\end{tabular}

Notes: Means \pm SE within each column followed by the same lowercase letter are not significantly different (Duncan's test, $P>0.05$ ). 
Table 2 Mean developmental duration of immature stages of Amblyseius herbicolus after predation on Trialeurodes vaporariorum egg and cattail pollen (Typha orientalis) $\left(25 \pm 1{ }^{\circ} \mathrm{C}, 60 \pm 10 \% \mathrm{RH}\right.$ and 12:12 h (L:D) photoperiod).

\begin{tabular}{cccccc}
\hline \multirow{2}{*}{ Treatment } & \multicolumn{5}{c}{ Developmental duration (days) } \\
\cline { 2 - 6 } & Egg & Larva & Protonymph & Deutonymph & Egg to Adult \\
\hline $\mathrm{T} 1$ & $1.13 \pm 0.00 \mathrm{a}$ & $1.04 \pm 0.02 \mathrm{a}$ & $1.08 \pm 0.04 \mathrm{~b}$ & $1.15 \pm 0.02 \mathrm{~b}$ & $4.35 \pm 0.08 \mathrm{~b}$ \\
$\mathrm{~T} 2$ & $1.06 \pm 0.01 \mathrm{a}$ & $1.04 \pm 0.02 \mathrm{a}$ & $1.25 \pm 0.00 \mathrm{a}$ & $1.06 \pm 0.00 \mathrm{c}$ & $4.44 \pm 0.00 \mathrm{~b}$ \\
$\mathrm{~T} 3$ & $1.08 \pm 0.02 \mathrm{a}$ & $1.02 \pm 0.02 \mathrm{a}$ & $1.13 \pm 0.06 \mathrm{ab}$ & $1.04 \pm 0.02 \mathrm{c}$ & $4.16 \pm 0.08 \mathrm{c}$ \\
$\mathrm{T} 4$ & $1.15 \pm 0.06 \mathrm{a}$ & $1.06 \pm 0.00 \mathrm{a}$ & $1.21 \pm 0.02 \mathrm{ab}$ & $1.25 \pm 0.04 \mathrm{a}$ & $4.77 \pm 0.06 \mathrm{a}$ \\
\hline
\end{tabular}

Notes: Means \pm SE within each column followed by the same lowercase letter are not significantly different (Duncan's test, $P>0.05$ ).

developmental times of egg to adult were obtained in groups $\mathrm{T} 4$ and $\mathrm{T} 3$, respectively (Table 2). Although no significant differences were observed between groups $\mathrm{T} 1$ and $\mathrm{T} 2$, there were statistically significant differences among groups $\mathrm{T} 1$ (or T2), T3, and T4.

The oviposition rates of $A$. herbicolus adult females at day 1 were highest in group T2, which was $1.54,1.54$, and 2.15 times those in groups $\mathrm{T} 1, \mathrm{~T} 3$, and $\mathrm{T} 4$, respectively (Table 3). However, there were no significant differences among groups $\mathrm{T} 1$, $\mathrm{T} 3$, and $\mathrm{T} 4(P<0.05)$. A. herbicolus adult females in groups $\mathrm{T} 2$ and $\mathrm{T} 3$ at day 2 revealed the highest oviposition rates, which were 1.09 and 1.52 times those in groups T1 and T4, respectively; however, no significant differences in oviposition rates of $A$. herbicolus were found among groups T1, T2, and T3. Last, A. herbicolus adult females in group T2 within two days revealed the highest average oviposition rates, which were 1.32, 1.26, and 1.81 times those in groups $\mathrm{T} 1, \mathrm{~T} 3$, and $\mathrm{T} 4$, respectively. The average oviposition rate of $A$. herbicolus adult females in group T1 was not significantly different from that of group T3 $(P<0.05)$ (Table 3$)$.

\section{Discussion}

Some phytophagous mites (e.g. spider mites) and other small arthropods (e.g. whiteflies and thrips) are the most prominent targets of predatory mites in agroecosystems. Under moderate environmental conditions such as temperature and moisture, these target pests can concurrently breakout in greenhouses and fields. Therefore, to survive, develop, and reproduce, the biocontrol agents should have the capacity to prey on suitable natural target preys. Amblyseius swirskii successfully preyed on eggs and/or immature stages of whiteflies and thrips, as well as broad mites, simultaneously (Buitenhuis et al., 2015). The eggs of the Mediterranean flour moth Ephestia kuehniella were a suitable food source for A. swirskii and N. cucumeris because

Table 3 Oviposition rates of Amblyseius herbicolus after predation on Trialeurodes vaporariorum egg and cattail pollen (Typha orientalis) after 24 and $48 \mathrm{~h}$.

\begin{tabular}{cccc}
\hline Treatment & Day 1 & Day 2 & Average \\
\hline T1 & $0.46 \pm 0.03 \mathrm{~b}$ & $0.46 \pm 0.04 \mathrm{a}$ & $0.46 \pm 0.02 \mathrm{~b}$ \\
T2 & $0.71 \pm 0.04 \mathrm{a}$ & $0.50 \pm 0.00 \mathrm{a}$ & $0.60 \pm 0.02 \mathrm{a}$ \\
T3 & $0.46 \pm 0.03 \mathrm{~b}$ & $0.50 \pm 0.01 \mathrm{a}$ & $0.48 \pm 0.02 \mathrm{~b}$ \\
T4 & $0.33 \pm 0.04 \mathrm{~b}$ & $0.33 \pm 0.04 \mathrm{~b}$ & $0.33 \pm 0.04 \mathrm{c}$ \\
\hline
\end{tabular}

Notes: Means \pm SE within each column followed by the same lowercase letter are not significantly different (Duncan's test, $P>0.05$ ). 
both phytoseiid species could develop from egg to adult (Delisle et al., 2015). In addition, a couple of studies confirmed $A$. herbicolus could predate and reproduce on the immature stages of S. staphylinus in New Zealand (Lam et al., 2019) and on the eggs of Bemisia tabaci (Gennadius) in Brazil (Cavalcante et al., 2015). Amblyseius herbicolus females were found to have the lowest mean duration of immature stages ( $4.86 \pm 0.19$ day) and the highest fecundity (48.2 \pm 1.85 eggs/female) when feeding on Pseudodendrothrips mori compared with $T$. urticae and the date palm pollen (Moghadam et al., 2010). In our study, $A$. herbicolus could feed and develop to adults, and reproduce when fed with $T$. vaporariorum eggs, either as nymphs or adult females. Nevertheless, the immature developmental duration of $A$. herbicolus was significantly longer on T. vaporariorum eggs alone than on Typha orientalis pollen alone or the mixed diets, revealing the $T$. vaporariorum eggs alone were of inferior quality. We predicted the delayed immature developmental duration of $A$. herbicolus feeding and reduced oviposition rates on whitefly eggs would ultimately result in slower population growth in greenhouses and under field conditions. However, some studies suggested the low performance of phytoseiid mites such as $A$. swirskii fed on whiteflies or thrips or spider mites alone, indicated that although these predators can complete their immature development when fed this diet, they potentially cannot reproduce (Delisle et al., 2015; Janseen and Sabelis, 2015). In the present study, when comparing with other groups, the average predation rates and oviposition rates of $A$. herbicolus adult females in group T4 were lowest, and development time was longest. The explanation for these differences in development and reproduction of these phytoseiid predators may be due to the deficiency of nutrients in the target prey alone (Muñoz-Cárdenas et al., 2014; Bouvet et al., 2019) and/or the difference of the nutritional requirements of different developmental stages of predators (Schultz et al., 2019).

In general, generalist predators are widely used as prominent biological control agents worldwide because they can prey on phytophagous mites as well as on other small arthropods such as whiteflies and thrips. Indeed, they can also feed and reproduce on different types of pollen (Nomikou et al., 2003; Hoogerbrugge et al., 2011; Kolokytha et al. 2011; Delisle et al., 2015; Liu \& Zhang, 2017; Tsolakis et al., 2019; Nemati et al 2020; Pascua et al. 2020; Yazdanpanah et al. 2021). When prey are rare or even absent, or when prey quality is low, pollen functions as supplementary food for the predators (insects and mites) (Tuovinen and Lindqvist, 2010). Moreover, pollen also serves as a favorite food source of immature stages of several phytoseiid mites (Vantornhout et al., 2004). Other studies also indicated the higher reproductive potential of the predatory mite $N$. californicus and Typhlodromus bagdasarjani on pollen compared with their natural prey (Riahi et al., 2016; Khanamani et al., 2017). The provision of pollen as supplementary food source on greenhouse-grown strawberries increased thrips and whitefly control of A. limonicus and A. swirskii. (Hoogerbrugge et al., 2011). The predacious mites $A$. swirskii and $N$. cucumeris could develop and reproduce when fed on pollens (maize, cattail, and apple) (Delisle et al., 2015). Our result suggested that $A$. herbicolus can prey on $T$. vaporariorum eggs when fed with $T$. orientalis pollen at the different developmental stages of protonymph/deutonymph or adult female. Furthermore, this study also found that $A$. herbicolus can develop and reproduce when fed with $T$. orientalis pollen either at protonymph/deutonymph or adult stage during the life cycle. A similar result was reported by Kolokytha et al. (2011), in which nine different plant pollens were all suitable for the immature stages, development, and reproduction of the predacious mite Typhlodromus athenas Swirski and Ragusa. A possible explanation for this could be due to the role played by the nutritional values of different pollens. In fact, previous studies have indicated that cattail pollen was considered a low-cost alternative food source with high nutritional value for some phytoseiid species such as Euseius scutalis and A. swirskii (Nomikou et al., 2003), A. limonicus (Liu \& Zhang, 2017; Lee \& Zhang, 2018; Lam et al., 2019), and Typhlodromus athenas (Kolokytha et al., 2011). In addition, Moghadam et al. (2010) reported that date palm pollen may variously be used as an alternative food of $A$. herbicolus in the absence of primary food. Therefore, we consider that predatory mites utilize pollens when prey is scare to increase survival and maintain their population in the crops. Indeed, under greenhouse and field conditions, many 
kinds of pollens could be used as alternative/supplementary food sources for predaceous mites, not only to provide nutritional ingredients but also to sustain the population of predators before target preys become available (Lee \& Zhang, 2018; Palevsky, 2017; Vangansbeke et al., 2016; Warburg et al., 2020).

The mixture of food sources has positive and/or negative effects on the developmental and reproductive performances of predatory insects and mites controlling the target pests, as well as on their population growth rates (Messelink et al., 2008; Muñoz-Cárdenas et al., 2014; Janseen \& Sabelis, 2015; Samaras et al., 2019, 2021). The quality of food source during the immature development is a key determinant of both fecundity and fertility in the mature stages of insects (Awmack \& Leather, 2002). The suitability of the mixture of different food sources potentially showed positive effects on the performances of predators. For example, mixed diets were considered the most suitable for coccinellids development because the reproductive parameters of predators were significantly influenced by the diet consumed (Bouvet et al., 2019). A significant increase of the intrinsic growth rate of a predator Balaustium population was found when predators fed on a mixture of $T$. vaporariorum and $T$. urticae eggs compared with other diets (Muñoz-Cárdenas et al., 2014). Furthermore, a laboratory experiment by Messelink et al. (2008) with the predatory mites A. swirskii and Euseius ovalis demonstrated that the densities of predators were up to 15 times higher in the presence of both two major greenhouse pests Frankliniella occidentalis and T. vaporariorum than in the single-pest treatments because of a higher juvenile survival and developmental rate on a mixed diet. In the present study, results demonstrated that the average oviposition rates and developmental times from egg to adult of A. herbicolus in groups T2 and T3 were all higher and shorter, respectively, compared with groups T1 and T4. Additionally, the average oviposition rate in group T2 was the highest and the development time from egg to adult of $A$. herbicolus in group T3 was the shortest. The oviposition rates were affected by the previous food source of the adult predatory mites (Sabelis, 1990) and the peak oviposition rates of predatory mites were known to be a good stand-in parameter for population growth rates (Janssen and Sabelis, 1992). In our study, cattail pollen was added to the mixture of diets of different stages of $A$. herbicolus. Cattail pollen functioned as a supplementary ingredient in the mixed diet to elevate the nutritional values of the primary prey or in the early establishment of some phytoseiid species in crops (Nomikou et al., 2003; Kolokytha et al., 2011). We consider that the mixture of pollen and whitefly eggs were suitable for different developmental stages of $A$. herbicolus and indicated the positive effects on the development and reproduction of $A$. herbicolus. As a generalist facultative predator of type III, A. herbicolus can feed on a wide range of food types including thrips, whiteflies, phytophagous mites, and pollen from different plant species (Argov et al., 2002; Cavalcante et al., 2015; Hoogerbrugge et al., 2011; Lam et al., 2019; Marcossi et al., 2020; Moghadam et al., 2010). As an indigenous predatory mite in New Zealand, $A$. herbicolus can better adapt to the local conditions, which would ensure a greater chance of successful control of the target pests, including whiteflies. The suitability of cattail pollen and whitefly eggs as a diet for $A$. herbicolus, therefore, is an indication that mixed diets have the potential to support this predatory mite in controlling the target pest species in the agroecosystem. The ability of $A$. herbicolus to successfully complete development on whitefly eggs suggested it is a potential predator for controlling whitefly in biological control programs. Further comprehensive investigations under field conditions are necessary to test the potential suggested in this laboratory study.

\section{Acknowledgements}

This research was supported in part by National Natural Science Foundation of China (Grant No. 31760621) and Natural Science Foundation of Jiangxi Province, China (20181BAB204005). We are grateful to Anne Austin (Manaaki Whenua - Landcare Research, Palmerston North) for improving the English presentation of this manuscript, and to Zane McGrath and Chris Winks 
(Manaaki Whenua - Landcare Research, Auckland) for help in providing technical assistance in maintaining plants in the greenhouse. Constructive comments by two anonymous reviewers and the editor of Acarologia, Dr Eric Palevsky, are also greatly appreciated. Tian-Rong Xin was sponsored by China Scholarship Council (Grant No. 201906825025). Tian-Rong Xin thanks Qing-Hai Fan (Ministry for Primary Industries, New Zealand) for encouragement and support provided to her, Min Ma (Shanxi Agriculture University) for teaching her species identification and Xin-Yao Gu (Guizhou University) for generous help to her. Zhi-Qiang Zhang was supported in part by the core funding of New Zealand Government for Crown Research Institutes from the Ministry of Business, Innovation and Employment's Science and Innovation Group.

\section{Conflict of interest}

The authors declare that they have no conflicts of interest with the contents of this article.

\section{References}

Argov Y., Amitai S, Beattie G., Gerson U. 2002. Rearing, release and establishment of imported predatory mites to control citrus rust mite in israel. Biocontrol, 47(4): 399-409. https://doi.org/10.1023/A: 1015634813723

Awm Ac K.C.S., Leather S.R. 2001. Host plant quality and fecundity in herbivorous insects. Annu Rev Entomol, 47(1): 817-844. https://doi.org/10.1146/annurev.ento.47.091201.145300

Jprba B, Au B., Cm B. 2019. Life history traits of the coccinellids scymnus subvillosus and s. interruptus on their prey aphis spiraecola and a. gossypii: implications for biological control of aphids in clementine citrus. Biol. Control, 132: 49-56. https://doi.org/10.1016/j.biocontrol.2019.02.002

Buitenhuis R., Murphy G, Shipp L., Scott-Dupree C. 2014. Amblyseius swirskii in greenhouse production systems: a floricultural perspective. Exp. Appl. Acarol, 65(4): 451-464. https://doi.org/10.1007/ s10493-014-9869-9

Burnett T. 1949. The effect of temperature on an insect host-parasite population. Ecology, 30(2): 113-134. https://doi.org/10.2307/1931181

CABI, 2017. Center for Agriculture and Biosciences International, Invasive Species Compendium. Trialeurodes vaporariorum (greenhouse whitefly) http://www.cabi.org/isc/datasheet/54660.

Cavalcante A.C.C., Vicente, D.S.V.L., Ca Roline, R.L., Moraes Gilberto José de. 2015. Potential of five Brazilian populations of Phytoseiidae (Acari) for the biological control of Bemisia tabaci (Insecta: Hemiptera). J. Econ. Entomol, 108(1): 29-33.

De Moraes G.J, Mesa N.C. 1988. Mites of the family Phytoseiidae (Acari) in Colombia, with descriptions of three new species. Int. J. Acarol, 14(2): 71-88. https://doi.org/10.1080/01647958808683790

Delisle J.F., Brodeur J., Shipp L. 2015. Evaluation of various types of supplemental food for two species of predatory mites, Amblyseius swirskii and Neoseiulus cucumeris (Acari: Phytoseiidae). Exp. Appl. Acarol, 65(4): 483-494. https://doi.org/10.1007/s10493-014-9862-3

Döker I., Stathakis, T.I., Kazak, C. 2020. The genus Amblyseius Berlese (Acari: Phytoseiidae) in Turkey with discussion on the identity of Amblyseius meridionalis. Syst. Appl. Acarol, 26(8): 1395-1420. https://doi.org/10.11158/saa.25.8.4

Duarte M.V.A., Venzon M., Bittencourt M.C.d.S., Rodríguez-Cruz F.A., Pallini A., Janssen A. 2015. Alternative food promotes broad mite control on chilli pepper plants. BioControl, 60: 817-825. https://doi.org/10.1007/s10526-015-9688-x

Greenberg S.M, Jones W.A, Liu T.X. 2002. Interactions among two species of Eretmocerus (Hymenoptera Aphelinidae), two species of whiteflies (Homoptera: Aleyrodidae), and tomato. Environ entomol, 31(2): 397-402. https://doi.org/10.1603/0046-225X-31.2.397

Hajizadeh J, Nazari M. 2012. A checklist and key for the phytoseiid mites (Acari: Phytoseiidae) of citrus orchards in Iran, with a new record for Iranian phytoseiid mites. Syst. Appl. Acarol, 17(4): 388-396. https://doi.org/10.11158/saa.17.4.7

Han G.D., Su J., Zhang K., Chen J., Zhang J.P. 2020. The predatory mite Neoseiulus bicaudus (Mesostigmata: Phytoseiidae), a promising biocontrol agent of whitefly Bemisia tabaci (Hemiptera: Aleyrodidae). Syst. Appl. Acarol., 25 (12): 2273-2285. https://doi.org/10.11158/saa.25.12.10

Hoogerbrugge H., Houten Y.V., Knapp M., Bolckmans K. 2011. Biological control of thrips and whitefly on strawberries with Amblydromalus limonicus and Amblyseius swirskii. IOBC/WPRS Bulletin, 68: $65-69$.

Janssen A, Sabelis M.W. 1992. Phytoseiid life-histories, local predator-prey dynamics, and strategies for control of tetranychid mites. Exp. Appl. Acarol, 14(3-4): 233-250. https://doi.org/10.1007/BF01200566

Janssen A, Sabelis M.W. 2015. Alternative food and biological control by generalist predatory mites: the case of Amblyseius swirskii. Exp. Appl. Acarol, 65: 413-418. https://doi.org/10.1007/s10493-015-9901-8

Khanamani M., Fathipour Y., Talebi A.A, Mehrabadi M. 2017. Linking pollen quality and performance of Neoseiulus californicus (Acari: Phytoseiidae) in two $\square$ spotted spider mite management programmes. Pest. Manag. Sci, 73(2): 452-461. https://doi.org/10.1002/ps.4305 
Knapp M, Houten Y.V., Hoogerbrugge H., Bolckmans, K. 2013. Amblydromalus limonicus (Acari: Phytoseiidae) as a biocontrol agent: literature review and new findings. Acarologia, 53: 191-202. https://doi.org/10.1051/acarologia/20132088

Kolokytha P.D, Fantinou A.A, Papadoulis G.T. 2011. Effect of several different pollens on the bioecological parameters of the predatory mite Typhlodromus athenas Swirski and Ragusa (Acari: Phytoseiidae). Environ entomol, 40(3): 597-604. https://doi.org/10.1603/EN10276

Lam W., Paynter Q., Zhang Z.Q. 2019. Predation, prey preference and reproduction of predatory mites Amblydromalus limonicus (Garman), Amblyseius herbicolus (Chant) and Neoseiulus cucumeris (Oudemans) (Mesostigmata: Phytoseiidae) on immature Sericothrips staphylinus Haliday (Thysanoptera: Thripidae), a biocontrol agent of gorse. Syst. Appl. Acarol, 24(3): 508-519. https://doi.org/10.11158/saa.24.3.14

Lee M.H, Zhang Z.Q. 2018. Assessing the augmentation of Amblydromalus limonicus with the supplementation of pollen, thread, and substrates to combat greenhouse whitefly populations. Sci. Rep, 8(1): 1-14. https://doi.org/10.1038/s41598-018-30018-3

Li G.Y, Zhang Z.Q. 2016. Some factors affecting the development, survival and prey consumption of Neoseiulus cucumeris (Acari: Phytoseiidae) feeding on Tetranychus urticae eggs (Acari: Tetranychidae). Syst. Appl. Acarol, 21(5): 555-566. https://doi.org/10.11158/saa.21.5.1

Liu J., Zhang Z.-Q. 2017. Development, survival and reproduction of a New Zealand strain of Amblydromalus limonicus (Acari: Phytoseiidae) on Typha orientalis pollen, Ephestia kuehniella eggs, and an artificial diet. Int. J. Acarol. 43: 153-159. https://doi.org/10.1080/01647954.2016.1273972

Ma M., Fan Q.H. Zhang Z.Q. 2019. Amblyseiinae of New Zealand (Acari: Phytoseiidae): redescriptions, rediscoveries, new records, new combinations and keys to species. Zootaxa, 4658 (2): 201-222. https://doi.org/10.11646/zootaxa.4658.2.1

Marcossi Í., Fonseca M.M., Carbajal P.A., Cardoso, A., Pallini, A. \& Janssen, A. (2020) High-quality alternative food reduces cannibalism in the predatory mite Amblyseius herbicolus (Acari: Phytoseiidae). Exp. Appl. Acarol. 81: 189-200. https://doi.org/10.1007/s10493-020-00500-7

Martin J.H., Mound L.A. 2007. An Annotated Check List of the World's Whiteflies (Insecta: Hemiptera: Aleyrodidae). Zootaxa 1492. Magnolia Press, Auckland, New Zealand https://doi.org/10.11646/zootaxa. 1492.1.1

McMurtry J A, De Moraes G J, Sourassou N F. 2013. Revision of the lifestyles of phytoseiid mites (Acari: Phytoseiidae) and implications for biological control strategies. Syst. Appl. Acarol, 18(4): 297-320. https://doi.org/10.11158/saa.18.4.1

Medd N.C, GreatRex R.M. 2014. An evaluation of three predatory mite species for the control of greenhouse whitefly (Trialeurodes vaporariorum). Pest. Manag. Sci, 70(10): 1492-1496. https://doi.org/10.1002/ps.3794

Messelink G.J, van Maanen R, van Steenpaal S.E.F, Janssen A. 2008. Biological control of thrips and whiteflies by a shared predator: two pests are better than one. Biol. Control, 44(3): 372-379. https://doi.org/10.1016/j.biocontrol.2007.10.017

Muñoz-Cárdenas K., Fuentes L.S, Cantor R.F., Rodríguez C.D., Janssen A., Sabelis M.W. 2014. Generalist red velvet mite predator (Balaustium sp.) performs better on a mixed diet. Exp. Appl. Acarol, 62(1): 19-32. https://doi.org/10.1007/s10493-013-9727-1

Moghadam B.A.N., Hajizadeh J., Sendi J.J., Fard M.R. 2010. Influence of three diets on development and oviposition of the predatory mite, Amblyseius herbicolus (Acari: Phytoseiidae) under laboratory conditions. J Entomol Soci Iran, 30(1): 51-68.

Nemati, A., Riahi, E., Khalili Moghadam, A., Gwiazdowicz D.J., Bahari, M.R. \& Amini, P. 2019. Comparison of different pollen grains and a factitious prey as food sources for Amblyseius swirskii (Acari: Phytoseiidae). Syst. Appl. Acarol., 24(12): 2427-2438. https://doi.org/10.11158/saa.24.12.10

Nomikou M, Janssen A, Sabelis M W. 2003. Phytoseiid predators of whiteflies feed and reproduce on non-prey food sources. Exp. Appl. Acarol, 31(1-2): 15-26. https://doi.org/10.1023/B:APPA.0000005142. 31959.e8

Palevsky E. 2017. Pollen provisioning for the promotion of biological control by omnivorous phytoseiids in organic greenhouses. Acta Hortic. 1164: 383-390. https://doi.org/10.17660/ActaHortic.2017.1164.49

Pappas M.L, Xanthis C., Samaras K., Koveos D.S, Broufas G.D. 2013. Potential of the predatory mite Phytoseius finitimus (Acari: Phytoseiidae) to feed and reproduce on greenhouse pests. Exp Appl Acarol, 61(4): 387-401. https://doi.org/10.1007/s10493-013-9711-9

Pascua M.S., Rocca M., Greco N., De Clercq P. 2020. Typha angustifolia L. pollen as an alternative food for the predatory mite Neoseiulus californicus (McGregor) (Acari: Phytoseiidae). Syst. Appl. Acarol. 25: 51-62. https://doi.org/10.11158/saa.25.1.4

Patel K., Zhang Z.Q. 2017. Functional and numerical responses of Amblydromalus limonicus and Neoseiulus cucumeris to eggs and first instar nymph of tomato/potato psyllid (Bactericera cockerelli). Syst. Appl. Acarol. 22: 1476-1488. https://doi.org/10.11158/saa.22.9.12

Perdikis D., Kapaxidi E., Papadoulis G. 2008. Biological control of insect and mite pests in greenhouse solanaceous crops. Eur J Plant Sci Biotech, 2(1): 125-144.

Pirayeshfar F., Safavi S.A, Sarraf Moayeri H.R, Messelink G.J. 2020. The potential of highly nutritious frozen stages of Tyrophagus putrescentiae as a supplemental food source for the predatory mite Amblyseius swirskii. Biocontrol Sci Tech, 30(5): 403-417. https://doi.org/10.1080/09583157.2020. 1722798

Reis P.R., Teodoro A.V., Pedro Neto M., da Silva, E.A. 2007. Life history of Amblyseius herbicolus (Chant) (Acari: Phytoseiidae) on coffee plants. Neotrop. Entomol. 36: 282287. https://doi.org/10.1590/ S1519-566X2007000200016

Riahi E., Fathipour Y., Talebi A.A, Mehrabadi M. 2016. Pollen quality and predator viability: life table of Typhlodromus bagdasarjani on seven different plant pollens and two-spotted spider mite. Syst. Appl. Acarol, 21(10): 1399-1412. https://doi.org/10.11158/saa.21.10.10 
Rodríguez-Cruz F.A., Venzon M., Pinto C.M. 2013. Performance of Amblyseius herbicolus on broad mites and on castor bean and sunnhemp pollen. Exp. \& Appl. Acarol.60: 497-507. https://doi.org/10. 1007/s10493-013-9665-y

Samaras K., Pappas M.L., Fytas E., Broufas G.D. 2019. Pollen provisioning enhances the performance of Amblydromalus limonicus on an unsuitable prey. Front. Ecol. Evol, 7: 122. https://doi.org/10.3389/fevo. 2019.00122

Samaras K, Pappas M L, Pekas A, Wäckers F, Broufas G D. 2021. Benefits of a balanced diet? Mixing prey with pollen is advantageous for the phytoseiid predator Amblydromalus limonicus. Biol Control, 155: 104531. https://doi.org/10.1016/j.biocontrol.2021.104531

Shahbaz M., Khoobdel M., Khanjani M., Hosseininia A., Khederi S.J. 2019. Sublethal effects of acetamiprid on biological aspects and life table of Amblyseius swirskii (Acari: Phytoseiidae) fed on Aleuroclava jasmini (Hemiptera: Aleyrodidae). Syst. Appl. Acarol., 24: 814-824. https: //doi.org/10.11158/saa.24.5.7

Schultz H., da Silva E., de Lima Aguiar-Menezes E., Resende A.L.S, Silva A.R. 2019. Adequacy of Drosophila melanogaster as prey for the development and reproduction of Coleomegilla maculata. BioControl, 64(1): 43-54. https://doi.org/10.1007/s10526-018-09912-2

Soltaniyan A., Kheradmand K., Fathipour Y., Davoud S. 2018. Suitability of pollen from different plant species as alternative food sources for Neoseiulus californicus (Acari: Phytoseiidae) in comparison with a natural prey. J. Econ. Entomol, 111(5): 2046-2052. https://doi.org/10.1093/jee/toy172

Spence E.L, Chandler D., Edgington S., Berry S. D., Martin G., O'Sullivan C., Svendsen C., Hesketh H. 2020. A standardised bioassay method using a bench-top spray tower to evaluate entomopathogenic fungi for control of the greenhouse whitefly, Trialeurodes vaporariorum. Pest. Manag. Sci., 76(7): 2513-2524. https://doi.org/10.1002/ps.5794

Tsolakis H., Sinacori M., Ragusa E., Lombardo A. 2019. Biological parameters of Neoseiulus longilaterus (Athias-Henriot) (Parasitiformes, Phytoseiidae) fed on prey and pollen in laboratory conditions. Syst. Appl. Acarol. 22: 1757-1768. https://doi.org/10.11158/saa.24.9.12

Tuovinen T., Lindqvist I. 2010. Maintenance of predatory phytoseiid mites for preventive control of strawberry tarsonemid mite Phytonemus pallidus in strawberry plant propagation. Biol. Control, 54(2): 119-125. https://doi.org/10.1016/..biocontrol.2010.04.006

Vangansbeke D., Nguyen D.T, Aidenaert J., Gobin B., Tirry L., Clercq P.D. 2016. Establishment of Amblyseius swirskii in greenhouse crops using food supplements. Syst. Appl. Acarol, 21(9): 1174-1184. https://doi.org/10.11158/saa.21.9.2

Yazdanpanah S., Fathipour Y., Riahi E. 2021. Pollen grains are suitable alternative food for rearing the commercially used predatory mite Neoseiulus cucumeris (Acari: Phytoseiidae). Syst. Appl. Acarol., 26: 1009-1020. https://doi.org/10.11158/saa.26.5.14

Warburg S., Inbar M., Gal S., Salomon M., Palevsky E., Sadeh, A. 2019. The effects of a windborne pollen-provisioning cover crop on the phytoseiid community in citrus orchards in Israel. Pest Manag Sci., 75: 405-412. https://doi.org/10.1002/ps.5129

Yang J., Lv J., Liu J, Xu X.N., Wang E.D. 2019. Prey preference, reproductive performance, and life table of Amblyseius tsugawai (Acari: Phytoseiidae) feeding on Tetranychus urticae and Bemisia tabaci. Syst. Appl. Acarol, 24(3): 404-413. https://doi.org/10.11158/saa.24.3.6

Zhang X., Lv J, Hu Y., Wang B., Chen X., Xu X., Wang E.D. 2015. Prey preference and life table of Amblyseius orientalis on Bemisia tabaci and Tetranychus cinnabarinus. PloS One, 10(10): e0138820 https://doi.org/10.1371/journal.pone.0138820 